\title{
The phenomenon of responsibility: between incontinence and hypercontrol
}

KEYWORDS

responsibility, hypercontrol, freedom, impulses

\begin{abstract}
The paper contains a phenomenological and theoretical analysis of responsibility treated as the capacity of personal causation (taking the role of the cause of one's actions) based upon conscious awareness and self-detachment from the immediate stream of one's living. The manifestations of the lack of responsibility are the failure to manage one's actions in the face of multiple forces majeures, incontinence of immediate wishes and impulses, or rigid hypercontrol over these impulses. Special sections are devoted to interrelations between responsibility and freedom, especially in the developmental aspect, and responsibility for another person.
\end{abstract}

Adam Mickiewicz University Press, pp. 33-48

ISSN 2300-0422. DOI 10.14746/kse.2019.15.3

ORCID: https://orcid.org/0000-0003-2252-9805

The phenomenon of responsibility is key for the existential interpretation of man. These issues, however, were not sufficiently or fully studied and developed, mostly with respect to the issue of freedom. Let us recall the example suggested by Viktor Emil Frankl ${ }^{1}$ : as an analogy to the Statue of Liberty erected on the eastern shore of the United States of America, it would be necessary to construct a Statue of Responsibility on its western shore.

* Dmitry Leontiev, doctor of psychology, head of the International Laboratory of Positive Psychology of Personality and Motivation, professor of the Faculty of Psychology of the Moscow Lomonosov State University (МГУ - Московский государственный университет), Moscor, Russia, dleon@mail.ru. The original translation from Russian into Polish is based on: Теория тичности А. Ф. Лазурского: от наклонностей к отношениям // „Методология и история психологии”, vol. 3, № 4, 2008, pp. 7-20.

1 V. E. Frankl, Człowiek w poszukiwaniu sensu, transl. by Aleksandra Wolnicka, Wydawnictwo Czarna Owca, Warszawa 2009. 
The issue of responsibility was described by German psychoanalyst Erich Fromm $^{2}$, who analysed the phenomenon of escape from freedom as being tied to the burden of responsibility. Psychology quite frequently uses the concept of "responsibility", to assign specific responsibility to a specific person ${ }^{3}$. Studies conducted during the recent decades (mainly by representatives of the psychology of personality) show that responsibility is a certain subjective causality. The assignment of responsibility is the assignment of the status of being the cause to a specific factor, in relation to emerging changes. In psychotherapy and clinical psychology, the indicated assignment describes the level and limits of responsibility of the psychotherapist or consultant ${ }^{4}$ in the therapeutic relation with the client ${ }^{5}$ (or patient), thereby describing the relations between the psychotherapist and the patient. The scope of responsibility is too subtle, but calls for special attention here. The case is similar with family relations.

Commonly, the concept of responsibility is correlated to the feeling of guilt. Responsibility hides within itself connotations of this term, for instance, one can chance upon penal or administrative responsibility. Responsibility applies to actions that took place in the past. It emerges when a situation arises, for which an individual bears specific consequences. However, the moment these negative circumstances do not emerge, responsibility does not arise. When we hear the words: "you will be held responsible for this", they are related to the future aspect. When something does take place, it shall be our role to clarify the effects, and, primarily, to bear responsibility. A breakthrough in the common understanding of responsibility takes place when we speak of responsibility for someone or something: for close ones, for the family, an issue to be taken care of or a social group. If we are able to get to the core of the concept of responsibility, then it will actually mean "presenting oneself in another's name, responding for others when they are called to bear responsibility". The moment I am responsible for my family, for the group I direct, for my country, then as a chosen leader - I am responsible. This encompasses a real sense. Let us also not forget the "responsible employee", taking upon themselves the responsibility of another. Is it at all possible to respond for another

${ }^{2}$ E. Fromm, Ucieczka od wolności, transl. by Olga i Andrzej Ziemilscy, Wydawnictwo Czytelnik, Warszawa 1978.

${ }^{3}$ B. Weiner, Judgments of Responsibility, New York, Guilford, 1995.

${ }^{4}$ In humanistic psychology, the psychotherapist is also considered the facilitator, meaning that they support the development of the person being analysed, however, they do not influence the result of therapy. In the learning process, the facilitator plays the role of a teacher who attempts to solve a specific dispute between parties [note by A. K.]

${ }^{5}$ In humanistic psychotherapy the term „client" is used frequently, whereas existential psychotherapy stresses the use of the term „patient” in the therapeutic process [note by A. K.] 
person (be responsible for them), and to what extent? We will come back to this question later. Right now we must respond to the question, what in essence is the phenomenon of responsibility? ${ }^{6}$

\section{The three modes of flying a plane}

Unlike animals, man can fragment, subdivide themselves. An individual knows what is happening with them (what takes place outside of their identity). They stress: I exist, and my life takes place, my actions, my behaviour, what arises between me and the world. The relationship between the fact that I consider myself as „me”, and that which takes place between me and the world, may refer to one of the following statements: „I am to no extent aware of what is happening with me, I do not separate myself from the present reality, my consciousness is not sufficiently reflective. I am completely fused with the process of life, an example of which are infants. I perform all activities on autopilot (without reflection and automatically). I am controlled by causal mechanisms: internal impulses, external stimuli, conditional relations and stereotypes. Accordingly, the entire mechanic of such autopilot behaviour, without a moment of reflection, awareness of changes, is described by behaviourism as described by Robert Cialdini" : „click-whirr”. We face diverse programmes, algorithms and cause and effect chains necessary to effect the mentioned activities, they operate on their own, and the „I" has nothing to do with it.

I reflect on the process taking place inside me, when I am able to discern my "I" from the flow of my life. To continue the autopilot metaphor, let us imagine that a pilot appears in the plane cabin, taking place beside the autopilot and not looking to hold the yoke. They watch, however, how the autopilot functions, meanby A. K.]

${ }^{6}$ See J. Filek, Filozofia odpowiedzialności XX wieku, Wydawnictwo Znak, Kraków 2003. [note

7 R. Cialdini, Wywieranie wplywu na ludzi. Teoria i praktyka, przeł. Bogdan Wojciszke, Gdańskie Wydawnictwo Psychologiczne, Gdańsk 2014.

8 „Ethologists, studying animal behaviour in their natural environment, have noted that in many species, certain fixed, mechanically repeated behaviour patterns emerge. These solidified behaviour patterns are noteworthy due to their similarity to the automatic reaction patterns in people (as click, whirr...). Both in people as well as in animals, the tendency is seen to release an entire system of such mechanical behaviour only upon emergence of a single, specific property in the vicinity. The capacity to react to such a property, meaning, the trigger, usually turns out to be very advantageous to the organism, as it enables the immediate execution of an action that is adequate to the situation, without any detailed and time-consuming analysis of all the available information". Ibidem, p. 30. [note by A. K., translated from Polish into English by the translator from Polish into English] 
ing, they control the entire process that takes place. The situation remains under control of causal effects and relations. However, I myself analyse the plane of the processes that arise, hence we may refer to the concept of the „victim” here. The signs of neurosis are generally related to good reflection upon and reception of the processes that emerge, but it seems impossible to make the decision to keep hold of the yoke. Everything that is happening to me, can cause fright, panic, but my efforts are worth nothing. Could it be any different? I am not able to change anything, the situation progresses on its own. Being dependent on systems of relations, seeing the multitude of sources that influence me, I turn numb as a rabbit before a constrictor.

The indicated situations include the known phenomenon of escape from freedom, described in the classic monograph by Erich Fromm?: People fear thinking about independently describing the trajectories of fate and modes of action. Ernest Nieznany stressed that nobody can force another not to become a slave in a free society. This is a fre choice. Let us recall the thesis of Andrei Voznesensky: „Unbearable is not the fact that I am forced to something, but that I act of my own will". Rollo May, writing about the causes of popularity of the famed book by Burrhus Frederic Skinner, Beyond Freedom and Dignity, noted that man is quite close to the thought that liberty is a figment of imagination, and all human behaviour is conditioned ${ }^{10}$. These words were written decades after Fromm, but presently the situation is not radically different. The tendency to „escape from freedom” and „escape from responsibility” looking to become the cause of future events, existed in the past, but remains presently, perhaps not dominant, but enticing in many respects. Iosif Brodsky warned graduates of a US university against this state of affairs: „Make all effort to avoid subscribing to the status of victims. Of all your body parts, most closely observe your index finger, as it is the one looking to unmask, to come out. The index finger is the sign of the victim, as opposed to the victory sign, and it becomes the synonym of surrender. Regardless of how hopeless your situation would be, do not blame external forces: history, the state, the government, race, parents, phases of the moon, your childhood or that you were taught how to use a chamberpot, etc." ${ }^{\prime 1}$.

In fact, we have gotten used to the fact that we refer to numerous determining factors that influence us: Outside forces, laws of nature, other people, social norms, cravings, customs, own internal impulses. We say: „I could not relent, I craved it so

${ }^{9}$ E. Fromm, Ucieczka od wolności, transl. by Olga and Andrzej Ziemilscy, Wydawnictwo Czytelnik, Warszawa 1978.

${ }_{10}$ R. May, Freedom and destiny, Norton, New York 1981, p. 137.

${ }^{11}$ И. Бродский, Речь на стадионе // Сочинения Иосифа Бродского: в 8 тт. СанктПетербург, Пушкинский фонд. Т. 6. 2000, pp. 116-117. 
much". When we refer to difficulties in controlling internal impulses, we conclude: "I am what I am, what can I do", ,this is the thug I am, this is how bad I am”, ,this is my structure, these are my relations, needs, impulses". As time passes, however, this seems quite convincing. When we remind ourselves that at quite a young age, practically everyone, perhaps not without difficulty, yet efficiently, learns such complicated activities as peeing and defecating, a reference to the fact that certain impulses and drives attract us in a specific direction and we are unable to handle them does not look so enticing after all. It was proven that asocial psychopaths who showed uncontrollable aggression, however, were able to control it by way of a new drug, pure placebo. In other words, we prefer to think in categories of advantages about the fact that there is something within us that we are not able to control, and hence we drift along the current of will. Let us consider the classic study by Walter Mischel ${ }^{12}$, who stressed that the ability to delay satisfaction, characterising human capacity to influence what is happening to them, correlates with personal development, turning out to be a significant parameter of maturity ${ }^{13}$.

Hence, the pilot stops using the autopilot and shifts to manual control. The „I" itself does not only reflectively separate itself from the flow of life, from what is happening to me, but I can also gradually halt the operation of causes, factors that influence me. Reflection is a necessary condition for this type of activity, but it is not a sufficient condition. We are dependent on many forces and factors, they are not, however, the cause of human activities. The following question can be put forward: Why am I speaking at a specific moment, why don't I take a break, go to the buffet and have a coffee or a beer? Many different reasons can be given: I perceive the expectations of the public, hence it is so important to do them justice and maintain my professional reputation, because I receive remuneration, and may lose it if I violate my obligations, etc. All these explanations do have a point, but neither can be a principle that is clarifying and provides the ultimate answer to the question, why, despite everything, don't I go somewhere else? I shall stay. To the end, as if chained, I shall speak in this very hall. There is no causal relation here. The sole correct reply is reflecting on both the possibility of making a choice and leaving the hall as well as the possibility of remaining and continuing with

${ }_{12}$ A similar situation is noted by Philip Zimbardo and John Boyd in their book The Time Paradox. In this publication, we find out that when we delay gratification and are filled by the feeling of control, stability, thought and primarily patience in the temporal sense, our actions aimed at the future may give rise to constructive consequences [note by A. K.].

${ }^{13}$ W. Mischel, Objective and subjective rules for delay of gratification // Cognition in Human Motivation and Learning /ed. by G.d'Idewalle, W. Lens. Leuven: Leuven University Press; Hillsdale: Lawrence Erlbaum Associates, 1981, pp. 33-58. See W. Mischel, Test Marshmallow. O pożytkach płynących z samokontroli, transl. by Agnieszka Nowak-Młynikowska, Smak Słowa, Sopot 2015. 
one's obligation. I choose this second option, and I keep confirming this choice. Of course, these possibilities as well as all other potential options that we are faced with, are asymmetrical: Some possibilities are more appealing than others. Others are riskier, however we know full well that one does not always pick what is most appealing and optimal. Knowing the structure of the situation and the variants emerging for people in a given situation, they can shine through when we get to know the motivation, attractiveness, the values, probability of emergence of these or other results, we can determine, which behaviour variant would be best for one. People often act improperly. Moreover, the indicated statement permits the estimation of one's behaviour, however in the beginning we analyse their reflective consciousness - they operate "on autopilot". When we turn on the reflective consciousness, all expectations fail: If a given situation would for instance have six alternatives, there are none that could not be chosen independent of their level of attractiveness. I can think of a seventh one the psychologist would never get to know if they were to describe my situation from the outside.

I personally interfere in the factors describing my situation. „We could stop being loudmouth consequences in the great cause-and-effect chain of events and try to take over the role of causes"14. In such a case, I simply enter my own life as a causal factor. One of the components explaining this state of affairs is the pause that already Rollo May ${ }^{15}$ wrote about. It is found in the area of human freedom: The nature of freedom is found in the pause (interruption) between the stimulus and the reaction ${ }^{16}$. When instead of reacting immediately, we make a pause, the chain is interrupted. The „click-whirr” mechanism instantly becomes out of tune and diverse possibilities arise. Through the effect of the pause, I interrupt the influence of external and internal factors (in the traditional sense). The pause permits the disconnection of the „autopilot” and grab the „steering wheel”. At this point, one's behaviour regains its freedom and responsibility.

\section{The genetic aspect of freedom and responsibility}

Freedom is a form of activity, controlled in each of its facet. Responsibility constitutes an individual becoming aware of the ability to be the cause of changes taking place both within them as well as in the world, and the conscious control of this

14 И. Бродский, Состояние, которое мы называем изгнанием, или Попутного ретро // Сочинения Иосифа Бродского: в 8 тт. Санкт-Петербург.: Пушкинский фонд. Т. 6. 2000, p. 36.

15 Representative of existential psychology from the United States.

16 R. May, Freedom and Destiny, Norton, New York 1981. 
disposition ${ }^{17}$. Freedom and responsibility are similar states of affairs, and at first glance, the feeling even emerges of their identicality. Some authors stress the fact that responsibility and freedom are two sides of the same coin, and that they are inseparable. However convincing the data mmay be, freedom and responsibility become alike only at a certain stage, but they flow out of two different sources. Freedom gradually develops in course of various forms of activity, thanks to an individual regaining the right to their own activity and the value of its substantiation. Responsibility develops in the process of shaping of forms of self-control, in the moment of gradual takeover of control of various aspects of action and behaviour that were initially taken over by our parents when we were minors. In the beginning, we were characterised by limited ability to move about, we required care. Step by step, motorically, we control our behaviour, we move by ourselves, then we learn diverse modes of action, and later we define the objectives that until that point remained outside of us. One by one, self-sufficient meanings emerge that are different from the senses and the values of our family environment (and this frequently makes the parents wonder, when did the child learn that); it is a process of progressive emancipation, in course of which that component develops gradually that at a mature age takes the form of responsibility. Freedom and responsibility, not fully formed yet, may create various constellations. In course of two empirical studies youths were subjected to, ${ }^{18}$ it was shown that there are different relations between freedom and responsibility:

- the independent variant, as the most advanced, is found when freedom and responsibility actually become one;

- the impulsive quasi-freedom variant arises when there is no responsibility;

- the symbiotic quasi-responsibility variant is found with respect to external objectives and values as a result of lack of freedom;

- the conformal variant emerges when neither the former nor the latter mechanisms emerge ${ }^{19}$.

The difference between freedom and responsibility can also be seen in a situation of imprisonment, however, I am aware that I am starting to become the cause of these actions. I can understand that a certain situation is forcing me to act in

17 Д. А. Леонтьев, Очерк психологии тичности, Смысл, Москва 1997.

${ }^{18}$ E. Kaliteyevskaya, D. Leontiev, When Freedom Meets Responsibility: Adolescence As The Critical Point Of Positive Personality Development // A. Delle Fave (ed.) Positive Psychology. Special issue of Ricerche di Psicologia, 2004, anno XXVII, N 1, pp. 103-115. E. Kaliteyevskaya, I. Borodkina, D. Leontiev, E. Osin, Meaning, adjustment, and autodetermination in adolescence // Proceedings of the 2nd European Conference on Positive Psychology (in press).

19 Д. А., Леонтьев, Очерк психологии личности, Смысл, Москва 1997. 
a specific manner, but I face two options: I either act in the way the situation is forcing me to act, but I do not perceive these activities as mine and I seek the guilty party, or externally I act the same, in a sense (from the point of view of an observer - a behaviourist), but I accept the necessity of these actions, I understand their unavoidability. Perhaps this is due to religious approval or something else, hence I accept these actions as mine. This is responsible activity. An example of an act that is externally forced yet internally approved is the story of Hamlet as interpreted by Merab Mamardashvili ${ }^{20}$. Mamardashvili sees the core of the Shakespearean tragedy in the fact that Hamlet is found within similar circumstances. If seemingly at first it would seem understandable what he should do, who is to be killed and in what order: the term of the „wheel of fate” emerges, as Mamardashvili says, using the ancient metaphor. Hamlet is uncertain, he does not want to become a part of this automatic fusion of events, he tries to find a different way out, he problematises his entire journey and does not want to make it. In the final scene, he perishes, performing in the fifth act that which he did not want to do in the first. It is a very instructive event, a heroic demise that demonstrates the struggle against mechanical fusion of circumstances, against autopilots and causal chains, from which one does not alwayss emerge victorious. Hamlet's demise was never to be his fate.

\section{Non-alibi, soundness of mind and forces majeures}

The core of responsibility is to acknowledge my actions as my own, what I do myself and not what just happens to be, and, accordingly, to acknowledge myself as the cause of certain events. the formula of responsibility was expressed by Mikhail Zhvanetsky in the form of a proverb: „I only thank myself for everything”. This proverb refers to words expressed by Mikhail Bakhtin in the wonderful phrase "non-alibi in being" ${ }^{21}$. Most probably, nobody among philosophers and psychologists was able to show better than Bakhtin, in the existential aspect, the analysis of the issue of responsibility. The legal concept of alibi means actually the lack of any proof concerning a specific crime. Suitable non-alibi is actual participation in an event and responsibility for it ${ }^{22}$.

${ }^{20}$ М. К. Мамардашвили, Необходимость себя, Лабиринт, Москва 1996, р. 47.

${ }^{21}$ М. М. Бахтин, К философии поступка // Собр. Соч. Т.1. Москва: Русские словари; Языки славянской культуры, 2003, p. 39. See M. Bachtin, W stronę filozofii czynu, przeł. Bogusław Żyłko, Wydawnictwo słowo/obraz terytoria, Gdańsk 1997.

22 „Responsibility is described by Bakhtin effectively as „my non-alibi in being”. My responsibility, my irreplaceable responsibility - ireplaceable by even those closest of You that are most inti- 
Jean Paul Sartre identified responsibility with being the author of one's actions. It was also presented by Irvin Yalom in the chapter of his Existential Psychother$a p y^{23}$ devoted to responsibility. One can agree with this, with one reservation: responsibility is identified with authorship and causation not in the sense that I sit over a piece of paper and can write anything that springs to my mind. The core of responsibility is contained in the conviction that when I have already written something, I cannot pretend that it was not me and that something (external) caused me to do this. If I am the author, I should acknowledge my own script, because I cannot question that fact. All external causes and pressure do not remove the problem of my responsibility. „I personally am not guilty of anything. It's how I was educated” is the justification of a character in "The Dragon” by Evgeny Schwartz. „Everyone was educated - replies the hero - but why did you have to end up the first student?"24. The concept of responsibility is tied to one other term that is significant from the legal point of view - namely, the concept of sanity. Sanity is the ability to sign contracts, the possibility of making independent decisions. One is responsible for themselves, accepts in own name certain responsibilities, assuming that they shall at a certain point be executed. This criterion omits children and the mentally ill. One can also distinguish limited sanity or functional insanity, related to affect. One of the fundamental issues of court psychological expertise is an attempt at determining, whether a disabled capacity of man exists to be responsible for their own actions due to affect. Farid Safuanov studied the problem of limited sanity as limitation of man's freedom of choice, analysing factors that may limit the freedom of choice. He tied them to legal categories in which limitation of sanity is classified as a reduction of responsibility for one's actions ${ }^{25}$. A comprehensive reduction of the issue of sanity to freedom of choice is incomplete if a higher level of behaviour control ensures is related to such a state that Arkady and Boris Strugatsky characterised as follows: Maximum freedom is when man is unable to choose. The core of things is not random, but imperative: When man reaches that

mately related ze to me - provides by I with a distinguished significance, however this significance is rather a burden than satisfaction. As may be seen, proper, responsible action of the I that is true to the surrounding world (hence, You as well) describes a sort of raw, „obligatory unity”, at the same time it specifically is a condition of the most open, devoted, engaged, selfless, metaphysically charged reference of the I to the You. Without - so to speak - a „solid” I, the relation to You is threatened by fragility, accidentality, haste and exaltation. Bakhtin writes on this with quite founded pathos: „I life in a world of unavoidable reality, not accidental possibility". Ibidem, pp. 437-438. Conf. M. Bachtin, W strone filozofii czynu, transl. by B. Żyłko, Gdańsk 1997, p. 70. [note by A. K.]

${ }^{23}$ I. Yalom, Psychoterapia egzystencjalna, Anna Tanalska-Dulęba, Instytut Psychologii Zdrowia, Warszawa 2008.

${ }^{24}$ Е. Шварц, Дракон, Пермское кн. Изд-во, Пермь 1988, р. 269

25 Ф.С. Сафуанов, Психология криминальной агрессии, Смысл, Москва 2003. 
understanding of the essence of things, whereby they have no choice, they become its guide and part of the objective order of the world. This does not necessary describe maximum freedom, but certainly maximum responsibility and maximum subjective causality. A reference must also be made to another legal term related to the concept of responsibility. This is the concept of „force majeure", describing circumstances that liberate one from responsibility for obligations to be fulfilled. In line with the translation from French, force majeure describes a "higher power" violating the capacity to plan things, to describe their effects and bear responsibility for undertaken obligations: for natural disasters or actions of state that could not be foreseen. One of the properties of responsibility is resistance to stress-causing factors, changes of unforeseen events, affective disturbances and shocks that could violate the capacity to follow one's chosen path. If one is not sufficiently ready to experience the possible faults, swings, then any occurring change of mood turns out to be exactly this higher power questioning my plans for the future. Only the cause of events can be responsible for their effects. The readiness to be the cause of certain activities and the readiness to respond for their effects are psychologically inseparable states.

\section{Diagnosis of civilisation: The syndrome of uncontrollability}

The diagnosis of our time, of our civilisation, is a chasm between the readiness to be the cause of activity and the readiness to bear responsibility for their effects. In this case, we remain between acts and responsibility. The dislike emerges of the takeover of the steering wheel, we shift responsibility to the autopilot. This diagnosis may be described as the "syndrome of uncontrollability" or by the names of its creators as the "Chernomyrdin-Duremar syndrome”. Uncontrollability emerges when a specific process takes place inside of me beside my own will that is liberated in the external reality. I do not control this process, I do not hold myself to be a visible cause of it; the direct effect of this state of affairs is the alibi in being. Enuresis is a very good example of the uncontrollability of natural human instincts: The essence seems to be uncontrollability related to the libido, the struggle for power, the achievement of motivation, the maintenance of aggression. We spread our hands, saying: that's just how people are, how I am, that's the way I'm made. The most striking example of this syndrome is the chasm between actions and effects: „they tried their best, it came out as usual” (Viktor Stepanovich Chernomyrdin). One of the final scenes of the film 'The Adventures of Pinocchio' shows the core of this syndrome precisely; as Carabas-Barabas suffers failure. Duremar 
dances on the side, smiling as he hums the following words: „It's not my thing, it's entirely not my thing....

The Chernomyrdin-Duremar syndrome describes the situation of „alibi in own life", the inability and unwillingness to take over responsibility. Responsibility is the third, higher level of relation between myself and what is happening with me, and ensures control over "natural” processes. People who would want to do their best, who honestly want to see a case to its happy end, however, who cannot quite achieve it. Merab Mamardashvilii believes that moral actions do not only assume longing; it is not enough to want good for it to come to pass. A small child may want to lift up a chest of drawers, but it doesn't have enough muscle and strength that would let it do this. It may hit the chest of drawers, but it won't accomplish anything. Mamardashvili puts it exactly the same way: In order to achieve a certain moral action, do good, it takes not so much the will of good, but it takes the „moral muscle". If this muscle is missing, then nothing can be accomplished.

In order to achieve every planned, purposeful and responsible activity with a specific, future-oriented result, a specific set of muscles is required. The illness of our time, of the entire Western civilisation (including Russia) is the syndrome of uncontrollability - the atrophy of moral muscle. Contemporary civilisation had created an enormous number of niches, in which life is possible on all kinds of autopilots, negating the development of higher forms of control of behaviour. Referring to terminology of the theory of Lev Vygotsky, contemporary Western civilisation in the face of mass media and its relevant economical, political mechanisms, is based on the cult of lower mental functions. The mechanisms become involuntary, automatic, basing on the "click-whirr” formula, submitting to manipulation. The delay of satisfaction and other forms of owning (oneself) cease to be necessary.

In this sense, the concept of illness is not so metaphorical any more: In the view of one author from the United States, the core of neurosis is reference to issues of responsibility. Each neurosis (and partly, psychosis) stands out by its inability to discern between situations and contexts, in which a specific choice and the takeover of responsibility are possible. hence, a Neurotic exerts a lot of energy to counter problems outside of their sphere of influence, and is unable to make decisions in the area of their own control zone $e^{26}$.

${ }^{26}$ M. K. Temerlin, On Choice and Responsibility in a Humanistic Psychotherapy // Severin F. T. (ed.) Humanistic Viewpoints in Psychology: A Book of Readings, McGraw-Hill, New York 1965. 


\section{Control of control and a dialogue with impulses}

It would be erroneous to oppose the failure to control and dampen impulses. Hypercontrol is the opposite of lack of control. If one desires to have control over everything, the inability to control the control itself arises. This phenomenon gains properties that make it involuntary, persistent, compulsive, outside of the scope of this control. An old, psychologically significant joke may be mentioned here, when a person came to find employment at a certain company. And so, they put to him questions about what they could do. The future employee says: „I can dig”. "And what else can you do?" „I am also able to not dig". In reality, this does not feel so funny: We frequently come across people who are able to dig, but not digging would not be so easy for them. These two capacities are equally important. „Not-digging” concerns the ability to take a break, to refer to a situation, to become aware of just where one is at that point, to understand own desires. Hypercontrol turns out to be just as unhealthy as the phenomenon of „uncontrollability”.

Both these extremes, these poles, concern the state of intense focus and control, maximum openness to the world: They are components of a unified cycle of human activity. Heinz Heckhausen developed together with his partners halfway through the 1980s the "Rubicon model”, establishing that when a particular decision is being made, a certain point exists, in which the mode of functioning changes. A person totally open to information from the most diverse kinds of sources weighs the alternatives as they are not ultimately shapes, they exist in a state of maximum openness, variability, readiness to take the most diverse of directions. The moment one makes a final decision, their mode of functioning changes suddenly. Heckhausen speaks of a shift from the motivational state to the volitional state of consciousness. Will defines a person removed from all other options, save for the one they have just chosen. They cease comparing, searching information, to be focused exclusively on the path chosen ${ }^{27}$.

In conquering both these extremes - uncontrollability and hypercontrol - it seems necessary to turn attention to the subtle mechanisms of inclusion of impulses, desires to the system of behaviour control. „Life is a dialogue with circumstances", as Andrei Donatovich Sinyavsky aptly put it. It is also necessary to conduct dialogue with one's cravings and impulses. Let us attempt to consider the modes of coping with one's own desires phenomenologically. We will analyse one of the most classic cases: desire that is sexual in nature. Let is say that there arises specif-

${ }_{27}$ Х. Хекхаузен, Мотивация и деятельность, 2., перераб. изд. Питер, Санкт-Петербург; Смысл, Москва 2003. 
ically in me a desire aimed towards a specific woman. In this, two typical cases are usually analysed. The first arises when I begin to undertake any sort of action that should, in the end, lead to the fulfilment of the desire. The other, opposing variant, is when I turn indignant towards myself, then I experience guilt and shame: But I am a family man, and I should furthermore be thinking about the company I am running, and here, an uncontrolled desire „of the flesh” arises. I strive to stifle this desire, thanks to the formula of A. and B. Strugatsky, I attempt to "consider the unexplainable phenomenon to be irrational, transcendental, one that does not actually exist, and remove it from the nation's memory once and for all'"28.

In reality, the continuation of the intermediate relation seems much more plausible. I can maintain this desire, de-reflectify the task and subsequently, immediately or at a later time, realise it. Perhaps this desire opens up before me something significant, it discloses the world of my own relations with women, but primarily it is an opening towards myself. The described phenomenon has a specific value to me. Entering into mature dialogue with my desire, it provides me with a lot of information about myself: „Only through desire and pain I can get to know the world, others, as well as myself" 29 . Who could know when and in what form could it be able to merge with other streams and factors determining my actions.

\section{Who for whom (takes responsibility)}

The ultimate aspect of the issue of responsibility that must necessarily be considered are interpersonal relations. The aspect of responsibility for another is current for psychotherapists, a proper description of it even exists: The psychotherapist is responsible for the work process, but they are not responsible for the result of the therapeutic process. Still, the problem is clear also in family interactions, in the relation between the citizen and the state that is responsible for them. The basis of analysis of this situation should be amended by the existential rule of indivisibility of responsibility: in a situation of cooperation, the measure of responsibility taken on by one person influences in no way the measure of responsibility that applies to another. These are different forms of responsibility.

The original, primary responsibility that arises in every person, is responsibility for themselves. This is responsibility in the strictest sense of the word: orig-

${ }_{28}$ А. Н. Стругацкий, Б. Н. Стругацкий, Понедельник начинается в субботу. Сказка о тройке, Terra Fantastica, Санкт-Петербург 1992, p. 345.

${ }_{29}$ М. К. Мамардашвили, Психологическая топология пути, РХГИ, Санкт-Петербург 1997, p. 53. 
inal, necessary and unavoidable. This responsibility means that man becomes the cause of their own actions. When a problem with responsibility would arise in me, I go to see a psychotherapist. I should follow the doctor's advice even if I sense the pressure of others (their reprehensible orders). In such a situation, the illusion of release from responsibility arises. If the commander bears full and absolute responsibility for the actions of their unit, how much of this responsibility remains with the soldiers themselves? The correct answer is: one hundred percent as well, because responsibility is not divisible. What is the commander or the mother in the family actually responsible for? What is the psychotherapist responsible for, the man who expands the frame of responsibility outside of themselves, and what is full and absolute responsibility for other participants of this cooperation? In relations between the state and citizens, the question is not about who is responsible for whom, but primarily, what the state is specifically responsible for, and what I myself am responsible for. What is manifested here is the removal between making a decision and the responsibility for actions, as described above, between one's entitlements and this specific muscle of action, without which it is impossible to effect the value of being the cause. The Chernomyrdin-Duremar Syndrome is experienced both by the state and by citizens: Everything happens for incomprehensible reasons, hence we spread our arms and say: „we tried our best”.

\section{Conclusions: Three sources and three components of responsibility}

I would like to conclude this article with an attempt at bringing the above musings down to a simple schematic that might become a useful tool bringing diverse aspects of responsibility in order. In psychology, going back all the way to William McDougall, issues of responsibility were made use of in various contexts. We have achieved a tripartite diagram of psychological processes and dispositions: the cognitive, the emotional and the effective components. If we would like to translate this diagram into the phenomenon of responsibility, then the cognitive component would turn out to be subjective causality and mechanisms of attribution: Do I perceive myself or external factors, fixed or situation-based factors to be the fundamental cause of what is happening to me, of what I am doing. Subjective causality is not identical with responsibility, it is only its cognitive component.

The emotional component of responsibility is bravery. It constitutes the readiness to take on diverse unexpected turns of events without altering the general 
orientation, own objectives, plans and the issue of why one chose to be the cause, the capacity not to give in to influences by diverse external forces, including force majeure. Man controls their own behaviour, is cognizant, capable and responsible for the actions they undertake. Any person, in whom this property is weakly expressed, remains under the constant influence of force majeure, which every external compulsion becomes.

An effective component of responsibility is the choice to act and the achievement of subjective causality. There are no right or wrong choices in one's life. Even from the perspective of time, knowing the consequences to which any one or another choice had led us, we cannot despite everything know whether that choice was best or worst if the consequences turned out to be bad or unwanted. Hence, from the existential point of view, the problem of choice turns out to be the following: a "good" choice is not a „correct" one, but a choice that is accepted as one's own responsible choice. Being aware that there can be no correct choice, one takes on the risk, accepting the lack of guarantee of results, and at the same time, bearing responsibility or running away from it, attempting to work as if this was the right choice and every other person would do the same. If at a later time something would turn out to be not the way it was supposed to be, I start searching for the guilty party: But I made the correct choice! The phenomenon of choice or escape from choice, meaning, the alibi, the phenomenon of responsibility or its avoidance finds its own, direct, effective expression. The issue of responsibility is understood to be an exit from the post-modern impasse of common relativity, a specific horizon and the loss of true and valuable indications or hints ${ }^{30}$. The path to the exit does not go through any objective, abstract truth, but through subjective reality thanks to the approval of senses and values, the action of a suitable personality that confirms its non-alibi in being. In the end, as the recently again popular ancient wisdom says: It is the awareness of the limits of one's own responsibility, the ability to discern between that, which we are able to change, from that, which we can only accept. Knowledge of the law liberates from irresponsibility.

Translated from Russian and edited by Aleksandra Kondrat Nicolaus Copernicus University moskwa.ros@gmail.com

30 Г. Л. Тульчинский, Постчеловеческая персонология. Новые перспективы свободы и рациональности, Алетейя, Санкт-Петербург 2002. 


\section{Bibliography}

M. Bachtin, „W stronę filozofii czynu”, transl. by Bogusław Żyłko, Wydawnictwo słowo/obraz terytoria, Gdańsk 1997.

R. Cialdini, „Wywieranie wpływu na ludzi. Teoria i praktyka”, transl. by Bogdan Wojciszke, Gdańskie Wydawnictwo Psychologiczne, Gdańsk 2014.

J. Filek, „Filozofia odpowiedzialności XX wieku”, Wydawnictwo Znak, Kraków 2003.

V. E. Frankl, „Człowiek w poszukiwaniu sensu”, transl. by Aleksandra Wolnicka, Wydawnictwo Czarna Owca, Warszawa 2009.

E. Fromm, „Ucieczka od wolności”, transl. by Olga and Andrzej Ziemilscy, Wydawnictwo Czytelnik, Warszawa 1978.

E. Kaliteyevskaya, D. Leontiev, When Freedom Meets Responsibility: Adolescence As The Critical Point Of Positive Personality Development // A. Delle Fave (ed.) Positive Psychology. Special issue of Ricerche di Psicologia, 2004, anno XXVII, N 1, pp. 103-115.

E. Kaliteyevskaya, I. Borodkina, D. Leontiev, E. Osin, Meaning, adjustment, and autodetermination in adolescence // Proceedings of the 2nd European Conference on Positive Psychology (in press).

R. May, „Freedom and destiny”, Norton, New York 1981.

W. Mischel, Objective and subjective rules for delay of gratification // Cognition in Human Motivation and Learning /ed. by G.d'Idewalle, W. Lens. Leuven: Leuven University Press; Hillsdale: Lawrence Erlbaum Associates, 1981, pp. 33-58.

W. Mischel, „Test Marshmallow. O pożytkach płynących z samokontroli”, transl. by Agnieszka Nowak-Młynikowska, Smak Słowa, Sopot 2015.

M. K. Temerlin, On Choice and Responsibility in a Humanistic Psychotherapy // Severin F.T. (ed.) Humanistic Viewpoints in Psychology: A Book of Readings, McGraw-Hill, New York 1965.

B. Weiner, „Judgments of Responsibility”, NewYork, Guilford, 1995.

I. Yalom, „Psychoterapia egzystencjalna”, Anna Tanalska-Dulęba, Instytut Psychologii Zdrowia, Warszawa 2008.

М. М. Бахтин, „К философии поступка” // Собр. Соч. Т.1. Москва: Русские словари; Языки славянской культуры, 2003.

И. Бродский, „Речь на стадионе” // Сочинения Иосифа Бродского: в 8 тт. Санкт-Петербург, Пушкинский фонд. Т. 6. 2000.

И. Бродский, „Состояние, которое мы называем изгнанием, или Попутного ретро” // Сочинения Иосифа Бродского: в 8 тт. Санкт-Петербург:: Пушкинский фонд. Т. 6. 2000.

Ф.С. Сафуанов, „Психология криминальной агрессии”, Смысл, Москва 2003.

А. Н. Стругацкий, Б. Н. Стругацкий, „Понедельник начинается в субботу. Сказка о тройке”, Terra Fantastica, Санкт-Петербург 1992,

Х. Хекхаузен, „Мотивация и деятельность”, 2., перераб. изд. Питер, Санкт-Петербург; Смысл, Москва 2003.

М. К. Мамардашвили, „Необходимость себя”, Лабиринт, Москва 1996.

М. К. Мамардашвили, „Психологическая топология пути”, РХГИ, Санкт-Петербург 1997.

Д. А. Леонтьев, „Очерк психологии личности”, Смысл, Москва 1997.

Г. Л. Тульчинский, „Постчеловеческая персонология. Новые перспективы свободы и рациональности", Алетейя, Санкт-Петербург 2002.

Е. Шварц, „Дракон”, Пермское кн. Изд-во, Пермь 1988. 